\title{
Article
}

\section{Football: a counterpoint to the procession of pain on the Western Front, 1914-1918?}

\author{
Adams, lain Christopher
}

Available at http://clok.uclan.ac.uk/11442/

Adams, lain Christopher (2014) Football: a counterpoint to the procession of pain on the Western Front, 1914-1918? Soccer \& Society, 16 (2-3). pp. 217231. ISSN 1466-0970

It is advisable to refer to the publisher's version if you intend to cite from the work. http://dx.doi.org/10.1080/14660970.2014.961377

For more information about UCLan's research in this area go to http://www.uclan.ac.uk/researchgroups/ and search for < name of research Group>.

For information about Research generally at UCLan please go to http://www.uclan.ac.uk/research/

All outputs in CLoK are protected by Intellectual Property Rights law, including Copyright law. Copyright, IPR and Moral Rights for the works on this site are retained by the individual authors and/or other copyright owners. Terms and conditions for use of this material are defined in the policies page.

\section{CLoK}

Central Lancashire online Knowledge www.clok.uclan.ac.uk

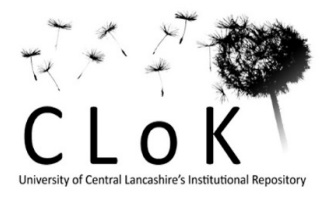


Football: a counterpoint to the procession of pain on the Western Front, 1914-1918?

Iain Adams

International Football Institute, University of Central Lancashire, Preston, UK.

Email: icadams@uclan.ac.uk 


\title{
Football: A counterpoint to the procession of pain on the Western Front, 1914-1918?
}

\begin{abstract}
In this article, three World War I artworks containing images of recreational football are analysed. These three images, In the Wings of the Theatre of War, Artillery Men at Football and Gassed, span the war from its beginning to its conclusion and are discussed in relationship to the development of recreational football in the front line area, the evolving policies of censorship and propaganda, and in consideration of the national mood in Britain. The paper shows how football went from being a spontaneous and improvised pastime in the early stages of the war to a well organised entertainment by war's end. The images demonstrate how the war was portrayed as a temporary affair by a confident nation in 1914 to a more resigned acceptance of a semi-permanent event to be endured by 1918, however all three artworks show that the sporting spirit, and hence the fighting spirit, of the British soldier was intact.
\end{abstract}

\section{Introduction}

Our folk memories of World War I (WWI) are of overwhelming slaughter, suffering and sacrifice. The appalling conditions suffered by the front line troops leave most people unaware that football, and other leisure activities, played an important part in the lives of many of the men. Sports historians know that mentioning football and WWI brings immediate images of the padre refereeing a game between the Germans and British during the first Christmas of the war or of plucky English troops demonstrating their defiance of death by dribbling and passing a ball as they went 'over the top'.

However, research shows that football was as much a part of life for the Tommy in the combat zone as it was on the home front. ${ }^{1}$ This paper examines three works of war art that include recreational football as a part of their visual narrative. The images are 'self-selecting' in that they may be the only artistic renditions of recreational football at the front from the time. Fortuitously they span the war from its beginnings in 1914 to its conclusion in 1918. The first image, In the Wings of the Theatre of War: Behind the centre of the fighting line in Belgium, is by Samuel Begg and was first 
published in The Illustrated London News (The ILN) of 5 December 1914. ${ }^{2}$ The second, Muirhead Bone’s Artillery Men at Football, is from either 1916 or 1917. ${ }^{3}$ The last art work to be considered is Gassed by John Singer Sargent; completed in 1919 from notes and sketches compiled in $1918 .{ }^{4}$

These images are evaluated in the light of the various stages of the propaganda and censorship policies of the British government and also with regard to the organisation of recreational football in the front line area as this provides important contextualisation for the consideration of the place of football within the overall pictorial narrative.

\section{Setting the Scene}

At the beginning of the First World War, Britain's Regular Army was probably the most highly trained and efficient in the world, however it was not large enough to survive a major European war; according to folklore the Kaiser called it 'a contemptibly small army’. The British Expeditionary Force (BEF) began embarking for France on 9 August 1914, taking part in its first major action at the Battle of Mons on the 23 August. After Mons and the following battle at Le Cateau, the allied forces retreated to the River Marne and then in a major offensive pushed the Germans back from immediately endangering Paris. In mid-September, above the River Aisne, the Germans dug in and the paradigmatic trench warfare of the Western front began. By October 1914 the only gap in the Western Front through which a significant thrust could be launched was in Belgian Flanders. This resulted in the First Battle of Ypres from 19 October to 22 November which ended in stalemate and an uninterrupted line of trenches from Nieupoort in Belgium to Pfetterhouse on the Swiss border, a distance of about 700 kilometres. By the end of 'First Ypres', the Regular British Army had been all but destroyed. ${ }^{5}$ The BEF, reinforced by regulars recalled from overseas duties, Territorials, 
reservists and Indian troops, occupied 35 miles of the frontline in Belgium and northern France; the new volunteer 'Kitchener’s’ units would begin arriving from May 1915.

The founding of The ILN in 1842 and its later competitors had led to the public being accustomed to seeing images of contemporary conflicts within weeks of the event; the Crimean War being the first to be reported in this way. Although photography had become ubiquitous by WWI, heavy equipment and long exposure times made outdoor action shots difficult. Army security attempted to restrict photography to the images captured by two army photographers and those made available to the press were, in the main, groups of arranged men and equipment showing a featureless No Man's Land or the area behind the lines and revealed little of allied misfortune, the mounting carnage and the suffering of the troops; death was the penalty for unauthorised photographs from the front. ${ }^{6}$ Newspapers, such as The $I L N$ were reliant upon solicited sketches from soldiers and these were often 'worked up’ by London based artists, such as Samuel Begg, into elaborate and highly professional drawings which were a 'highly skilled exercise of the imagination'. ${ }^{7}$ The sketch upon which In the Wings of the Theatre of War is based was probably supplied by a soldier of the BEF, a note under the title explains 'Drawn by S. Begg from a sketch by an eye-witness’ (see Figure 1).

WWI confronted the media 'with insuperable problems of censorship and obstruction'; to the generals who commanded the huge armies of the twentieth century 'news was too dangerous a commodity to be trusted to the hands of free-ranging correspondents and special artists' and so 'when the storm broke in August 1914, the military leaders had stoked up a fog of censorship that covered Europe from one end to the other. ${ }^{9}$ Winston Churchill, a former war correspondent of the Morning Post, and then First Lord of the Admiralty, stated 'The war is going to be fought in a fog. The best place for correspondence about this war will be in London. ${ }^{9}$ Artists were barred from 
the front until 1916 and therefore most people derived their visual images of the war from newspaper photographs supplied by the War Office and drawings ‘carefully edited to exclude anything too alarmist or defeatist. ${ }^{10}$ Newspaper editors did not want to upset the War Office and face the possibility of losing access to photographs.

\section{In the Wings of the Theatre of War}

Begg has been described as perhaps the finest black and white artist of his age and conversely as representing the worst features of late Nineteenth century illustrators in that the work was too close to technical perfection and resembled photographic scenes with no imaginative input. ${ }^{11}$ However, as a commercial illustrator Begg would have been keen to compete with photographers and provide

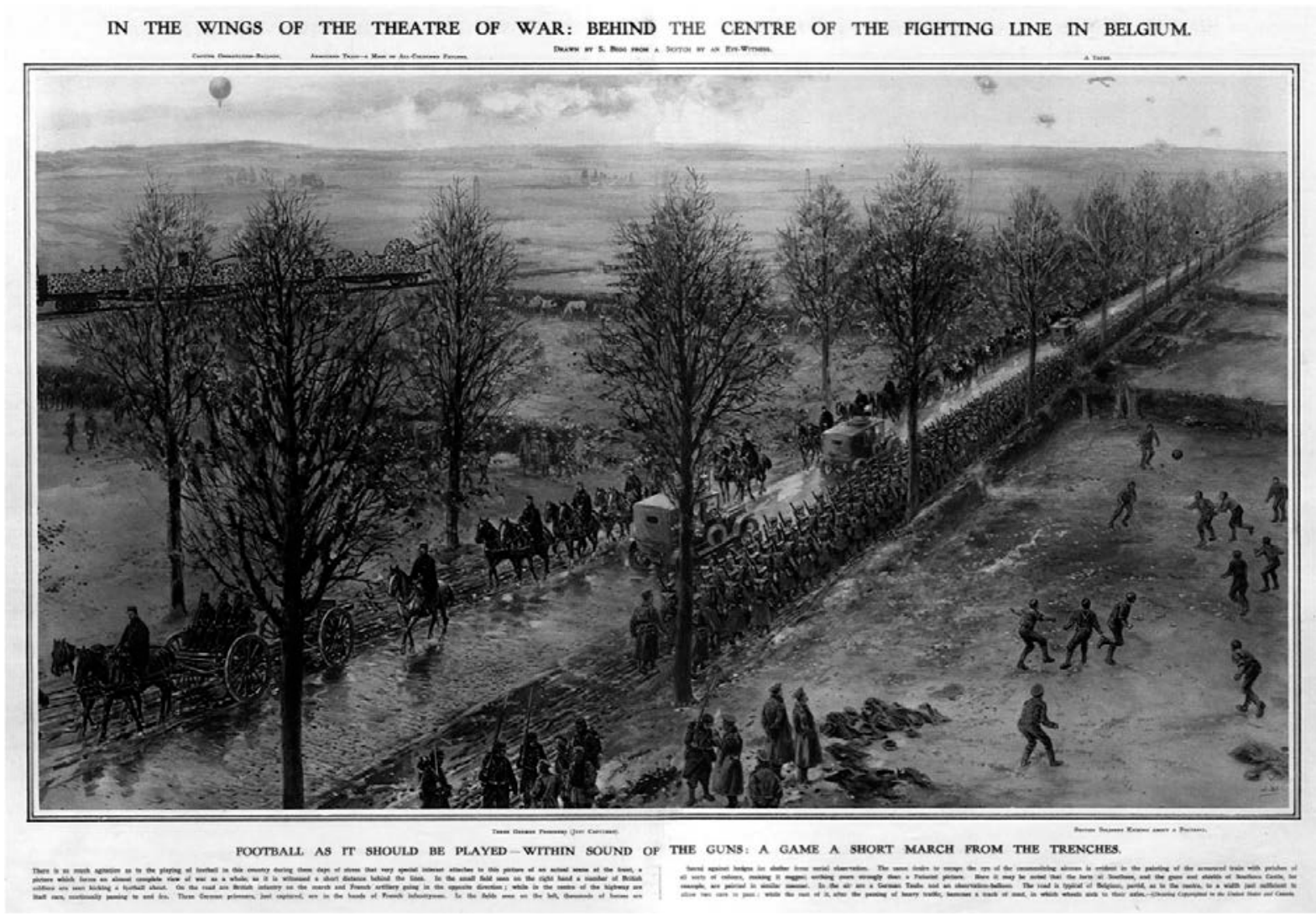

Figure 1. Samuel Begg, In the Wings of the Theatre of War. Courtesy of the Mary Evans Picture Library.

an 'eye witness' viewpoint. 
Here Begg provides a view of a British battalion marching smartly towards the front line as a French artillery column retires to rest. A British regiment, possibly cavalry as there are numerous horses sheltered in the lee of the hedges, enjoys a period away from the front with some of their number playing a scratch game of football. ${ }^{12}$ It can be assumed that their military duties for the day are done and the watching officers approve of their men's' activity, at least tacitly. The caption alludes to the furious argument taking place in Britain about the continuing professional football season:

There is much agitation as to the playing of football in this country during these days of stress that very special interest attaches to this picture of an actual scene at the front, a picture which forms an almost complete view of war as a whole, as it is witnessed a short distance behind the lines. In the small field seen on the right hand a number of British soldiers are seen kicking a football about. On the road are British infantry on the march and French artillery going in the opposite direction; while in the centre of the highway are Staff cars, continually passing to and fro. Three German prisoners, just captured, are in the hands of French infantrymen. In the fields seen on the left, thousands of horses are tethered against hedges in shelter from aerial observation. The same desire to escape the eye of the reconnoitring airman is evident in the painting of the armoured train with patches of all sorts of colours, making it suggest nothing more than a Futurist picture. Here it may be noted that the forts at Southsea, and the guns and shields of Southsea Castle for example, are painted in similar manner. In the air are a German Taube and an observation-balloon. The road is typical of Belgium, paved, as to the centre, to a width just sufficient to allow two cars to pass: while the rest of it, after the passing of heavy traffic, becomes a track of mud, in which wheels sink to their axles.

The presence of both French and British troops in Begg's image which is 'Behind the centre of the fighting line in Belgium' would indicate that this is during, or just after, the First Battle of Ypres when British and French troops worked together to beat off the repeated German attacks. Once the situation stabilized for winter, the British and French forces separated to specific areas of responsibility abutting at La Bassée in northern France and St Éloi in Belgium. This proposition of timing for the original sketch allows at least two weeks for posting and working up by Begg before publication. 
The casual use of the word 'futurist' demonstrates that The ILN's mainly middle-class readers were aware of the ferment of artistic creativity in Britain in the early $20^{\text {th }}$ century. The paper's reviews and reproductions of the Summer Exhibitions of the Royal Academy of Arts and a regular arts column had introduced them to postimpressionist art and other avant-garde movements alongside more traditional approaches. However, war images such as this helped to democratise art, as it conveyed the experiences of the ordinary Tommy to their families and paintings and drawings were easier to ‘spin' helping to shape opinion and transform attitudes.

In the Wings of the Theatre of War can be seen as a propaganda picture reassuring those at home that things are going well at the front; picturing the two allied armies’ together emphasizes their closeness and cooperation. The British army is in good spirits marching smartly to the front, success allows units to retire in good order for rest periods and enemy prisoners are being taken; the army Staff is in touch with events in the front line and the readers' sons, brothers and husbands are being paternally looked after by officers who understand their passion for sport. This provided reassurance that the soldiers were not being brutalised by their experiences and some of their civilian identity remains; perhaps encouraging the belief that the British were more 'sportsmanlike' than other nations reflecting their moral superiority and were retaining their sporting spirit which was deemed essential to winning this war. Most on the home front would have known about the great demand at the front for sporting papers as soldiers maintained their links to home. ${ }^{13}$ Perhaps Begg hoped that his picture could persuade potential recruits to do their duty and go to play 'The Greater Game’ because the familiar lesser game was available after duty was done; recruitment had dropped off to worryingly low numbers by this time. The picture also has an air of transience; the horses although well cared for are not in stables and there are no buildings visible for 
the men and they will be in bivouacs for the night. This is obviously a temporary resting place on the move forwards, conceivably the breakthrough is coming and the war will be over by Christmas, or shortly thereafter. The war is not a permanent state and young men should volunteer quickly before they miss it.

The soldiers have started a pick-up game of football on a rough field bounded by hedges alongside the road. Piles of great coats make up the goals although they have a proper ball. From September 1914, newspapers regularly published photographs of new soldiers in the training camps in Britain playing football emphasising its role in keeping soldiers fit, content and disciplined. At least two papers, The Sporting Life and The Daily Mail, launched public appeals to send footballs to each battalion in the country. By December 1914, the two papers had supplied over 650 balls to the army which, by then in Britain, had over 200 teams and a number of league and trophy competitions. ${ }^{14}$ Many of these footballs would have found their way to the front as the battalions finished their training and departed. Captain Elpheston of the 2/East Surrey’s, which embarked for France on 18 January 1915, thought that football not only built up his soldiers' physical fitness and stamina, but their courage and character alongside developing team work and an awareness of tactical manoeuvres. He wrote 'there are few better ways of preparing a regiment ... football has become an important feature of our preparations and when we leave for the front, we will leave with our footballs in our knapsacks.'15

Organised sport had been gradually developing since the late nineteenth century in the British army and nearly every battalion had a football team and army teams played in many civilian leagues local to their garrisons. ${ }^{16}$ By 1914 , football had many passionate promoters who appeared to believe that a British army without football could not be prepared physically or mentally for war. However sport was an unofficial 
pastime even though it had been recognised as an effective adjunct to formal physical training by The Physical Training Manual issued in 1908. This view was supported by Sir John French, then the Chief of the Imperial General Staff, who thought 'the proper organisation and supervision of Games ... most important'. ${ }^{17}$ In 1914 French was Commander-in-Chief of the BEF and the officers in Begg's illustration would have known that their commander approved of football even if they as individuals did not.

By the time of the publication of In the Wings of the Theatre of War, football was ubiquitous in the BEF, games snatched in any precious moments of respite as shown by Begg. On 4 October 1914 Captain James Jack of the Cameronians noted in his diary that the daily after-dinner routine, when out of the line, included 'ordinary duties, working parties and games - chiefly football.' In reserve, over Christmas, he observed that 'games, mainly football, in the afternoons keep them fit and cheery ... however tired the rascals may be for parades they have always energy enough for football' ${ }^{18}$ The press reported this importance of football to the front line troops; in November 1914, The Sporting Life noted that the game was being played 'in fields within the sound of guns' and The Daily Mail reported that the men were playing where 'the shells whistle half time. ${ }^{19}$ The Sporting Life said of the soldier:

His interest in football has saved him when the shrapnel has unnerved him or when the water-logged trench has shattered his faith in providence ... it has offered him something beyond the roar of the cannon and the scream of the shell. Indeed with his football beside him, he can move forward with the confidence he held when he first entered the trench. ${ }^{20}$

It is probable that most football at this stage of the war would have been played in a similar manner to Begg's illustration as the instability of the war of movement would not have allowed units to plan matches against others or build proper pitches as they were continuously on the move. 


\section{Artillery Men at Football}

By early 1915 football competitions and tournaments were being organised in France and Belgium at all levels from platoon to division as the war situation stabilised with the establishment of trench warfare. For example in January 1915 Brigadier-General Briggs of the $1^{\text {st }}$ Cavalry Brigade donated a cup for a brigade tournament and forty-five teams competed. ${ }^{21}$ In July 1915 Haig famously complained about the increasing number of men falling asleep on sentry duty and noted in his diary 'men should rest during the day when they know they will stand on sentry duty at night. Instead of resting they run about and play football', but by November it was said that 'every section has its team' ${ }^{22}$ Sport was still largely unofficial and tended to originate with the lower ranks and had different organisation across Divisions, Brigades, and Regiments. However, in March 1916, instructors of the Army Gymnastics staff were seconded to France for two months to present demonstrations at the Base Camps. They were then transferred to $3^{\text {rd }}$ Army School to put on short courses to qualify junior officers and NCOs as Physical and Bayonet Training instructors in their home units. ${ }^{23}$ In September 1916 the Physical and Bayonet Training staff was given overall responsibility for organising sport in the BEF, including equipment provision and the delivery of courses on sport organisation and ideology as well as encouraging the establishment of competitive structures. Sport was officially part of army training. ${ }^{24}$ Major-General Maxse, the reflective and flexible commander of the $18^{\text {th }}$ Division who was best known for his innovative and effective training methods which turned his division into 'probably the best fighting division possessed by the British Army', ordered his men to play 'football in the afternoons' because 'after a long spell in the trenches all ranks will be more-or-less rusty and slow in movement. ${ }^{25}$ 
The increasing recognition of the importance of sport by the General Staff may have been accelerated by the losses in the Battle of the Somme which began on 1 July 1916 and ended on 18 November 1916 resulting in an estimated 419,654 British casualties. ${ }^{26}$ Replacements brought into the affected units came from all over Britain and needed rapid assimilation to re-establish fighting capacity. Baynes analysis of the British army in WWI concluded that morale depended upon the regimental system developing pride and loyalty, mutual trust between officers and men, strong discipline and a sense of duty, all supported by an effective administration. ${ }^{27}$ Football and sport in general, was recognised by many surviving officers as being an important tool for developing 'close unit cohesion' and esprit de platoon. ${ }^{28}$ In August General Gough, commanding the $5^{\text {th }}$ Army, ordered that there should be a football ground in each

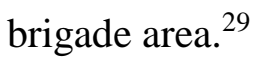

The brigade and divisional tournaments that had become established since early 1915 had continued to grow and had become significant entertainment events for soldiers out of the line. Most commanding officers insisted that tournaments began with as many soldiers as possible playing in the early stages before an elite team was chosen to represent the unit in the next round. Roberts opined that for most men 'the appeal of the tournament... became its potential to replicate the partisan spectator experience of association football' ${ }^{30}$

Concurrent with the increasing amount of football being played by British forces in combat zones was a growing demand for visual images of the troops and the fighting areas from the home front. In August 1914, the British Foreign Office had established Wellington House, a secret government agency to develop and disseminate propaganda to meet the requests for information at home and help sway opinion abroad in favour of the allies. This agency was headed by Charles Masterman, a liberal politician, who 
insisted that propaganda had to be reasonable and accurate and favoured informed argument and measured opinion. ${ }^{31}$ This idea was founded in the principle that it was better to 'draw people into supporting Britain’s “just” war' through portraying British society's liberal and socially inclusive values rather than traditional battle scenes of glory or blatant propaganda of ghastly Hun atrocities. ${ }^{32}$ In April 1916, Masterman set up a pictorial section which commissioned a wide variety of visual propaganda from war films to calendars and bookmarks. ${ }^{33}$ Many of the staff of Wellington House were established figures of the London art scene and it was decided to employ artists rather than studio illustrators such as Begg to help meet the demand. Most of the early illustrations in newspapers on both sides of the conflict had been completed in the heroic and triumphalist manner of traditional war art focussing on such subjects as easily romanticized glorious cavalry charges and heroic leaders; studio artists had not come to terms with the reality of industrialised warfare. These drawings were intended to shape readers' views of the events they were purported to record and as a result 'the public's notion of war was founded on pre-industrial romantic and patriotic imagery, and in 1916 these illusions were still being nourished by the handful of war reporters in France sanctioned by the British High Command. ${ }^{34}$ It became known to Masterman that Muirhead Bone, a Scottish etcher, had just been called up and he had a reputation for the 'rapid production of high-quality, accurate drawings that could be reproduced with ease. ${ }^{35}$ Masterman decided that Bone would be of more use creating images for the government than slogging through the mud of the trenches. ${ }^{36}$

On 12 July 1916 Bone was appointed as the first official war artist and sent out to the front in August where, with a high-level pass, he 'had virtual freedom to move when and where he liked and within the first few days had produced numerous preliminary sketches. ${ }^{37}$ He was urged to stress the realistic as well as the artistic and to 
include places whose names were known by the general public. ${ }^{38}$ It was also intended that his work would help create a permanent record of the war which would be housed in the Prints and Drawings Department of the British Museum. ${ }^{39}$ In his first seven week visit he produced 150 finished drawings and by 1917 he had made 500 detailed images for the government, from both the war and home fronts. There was an insatiable demand for his work and some of it was published in monthly magazines such as The Front Line and The Western Front as well as in pamphlets and portfolios aimed at neutral countries, especially the United States. Often commentaries were added by individuals such as C.E. Montague which turned Bone's 'factual statements into the appropriate propaganda. ${ }^{40}$ Bone’s ‘images of well-organised and managed efficiency proved to be popular with the public' and helped counter the unease as the cost of the Somme offensive became clear. His 'strangely reassuring and, at times, prosaic narratives' conveyed the transitions and transformations occurring at the front. ${ }^{41}$

In one image he captured the artillery being passively drawn to the firing line by horses and then, in another, the storm of industrialised violence released in barrages. In Artillery Men at Football (see Figure 2) he portrays the artillery at rest, refitting and relaxing away from the front. It is a detailed small black chalk and wash study, 330 by 533 millimetres, completed with a conventional topographical device of a slight darker rise to one side and a broad sweeping large sky. To the right is a collection of gun carriages, limbers and caissons with some soldiers working amongst them. From the centre foreground furrows lead downhill to a flat space in the middle distance where a football match is occurring. The game is being played across the image with scattered groups of soldiers on either touchline watching the action. The ball is moving high in the air towards the near touchline with a player in hot pursuit. The players are in normal army uniform showing that this match, as in Begg's illustration, may be an after duty 
kick-about but sports kit was still in short supply and formal matches were often played in breeches and shirt sleeves at this stage of the war. ${ }^{42}$ On the far side of the pitch are many bell tents, the living accommodation for the gunners.

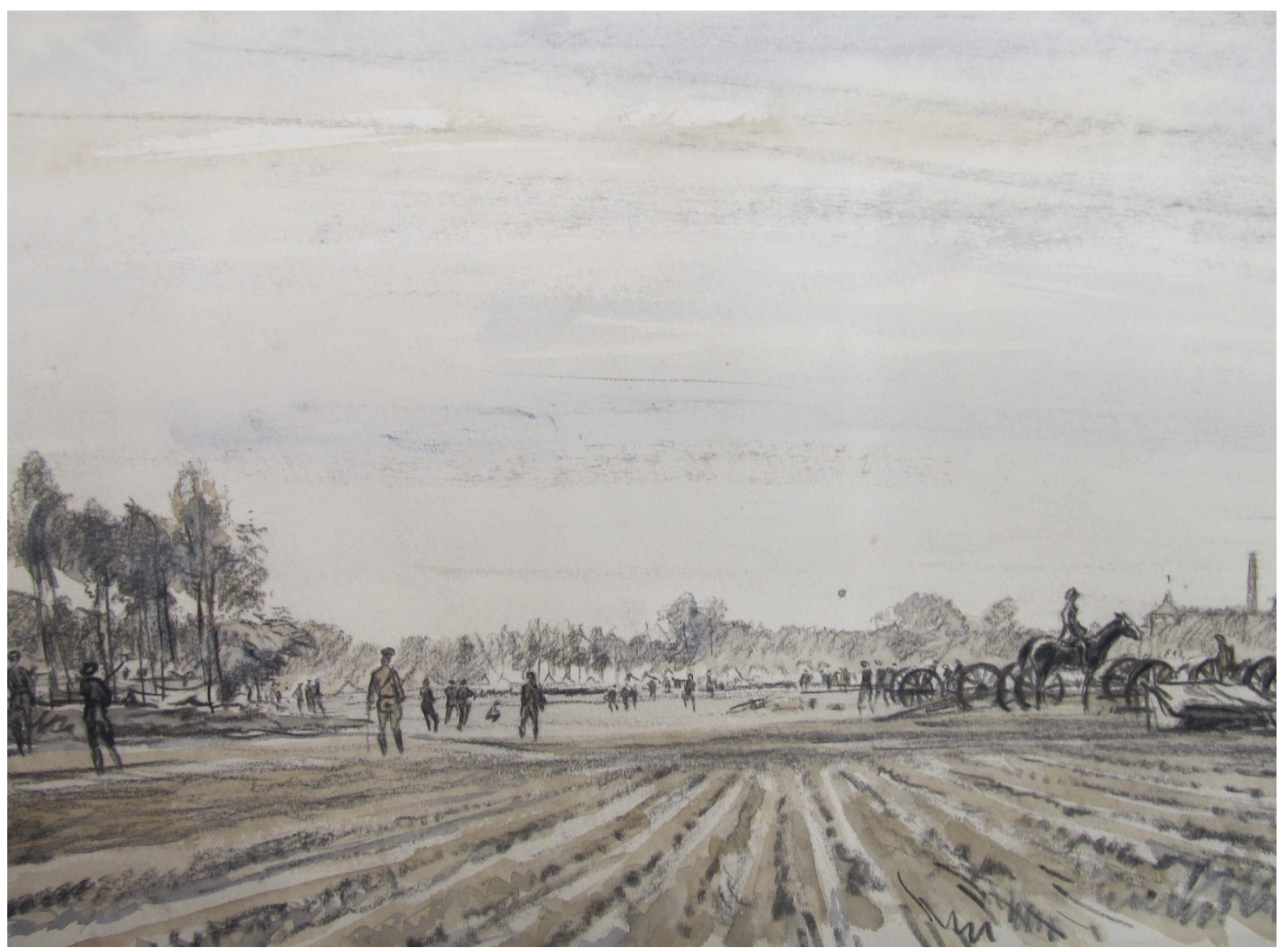

Figure 2. Muirhead Bone, Artillery Men at Football. Courtesy Natalie Bone \& The Bone Estate.

The image has body through the sombre blue, grey and brown washes. The lack of finish of much of his work in France 'lent an air of unquestionable authenticity' and evoked a feeling that it was personally observed and genuine. ${ }^{43}$ Bone wrote 'I did not like to imagine war scenes and so only drew what I saw, and this only when I had a chance to digest it. This limited me very much and I am afraid resulted in rather prosaic work. ${ }^{44}$ However, this gave it a freshness and spontaneity, perhaps partly because the work was completed en plein air, which indicated it was not fabricated, and by this stage of the war there was a growing mistrust of the interpretations being constructed by 
studio artists such as Begg and Caton Woodville. ${ }^{45}$ Many of Bone’s impartial recordings, such as Artillery Men at Football, are in pastoral settings with the developing technology of war interposed causing pause for thought. Coming after the opening days of the Somme, this would have been a reassuring and accessible image for families in Britain; the men and equipment are in good shape, and the soldiers, although working hard, still have time, energy and enthusiasm for football. Even though organised football was wide-spread, spontaneous unofficial kick-abouts still flourished. The stability of the war has enabled the establishment of semi-permanent well-ordered surroundings with even a large cleared open space for sports and drill.

\section{Gassed}

In March 1918, the British War Memorials Committee (BWMC) was established under the auspices of the Ministry of Information which had taken over Wellington House. This committee aimed to build 'a permanent legacy for future generations, an emblem of remembrance, and a lasting memorial expressed in art' which was to be incorporated into an imposing Hall of Remembrance. ${ }^{46}$ This marked a significant change in official war art moving from propaganda and recording the war to remembering the selfsacrifice of a citizen army saving the nation in the war to end all wars. It was decided that the artists had to work from personal experience and create their works while their passions and emotions were high. John Singer Sargent, an American portraitist and landscape artist living in London, was selected to capture 'the fusion of British and American forces' and arrived in France on 2 July $1918 .{ }^{47}$

On the 20 August, Sargent heard that the Guards Division was participating in a major offensive the following morning, the Third Battle of Albert, and decided to drive towards them after lunch the next day. En route, he diverted towards the 46 Casualty Clearing Station (CCS) on the Doullens Road at Bac-du-Sud where gas victims were 
being treated. ${ }^{48}$ Here he met 'a harrowing sight, a field full of gassed and blindfolded men'. ${ }^{49}$ According to his companion, fellow artist Henry Tonks, Sargent 'was very struck by the scene and immediately made a lot of notes. ${ }^{50}$ Following a severe case of influenza in September, when he was admitted to 41 CCS, Sargent returned to England and began work on Gassed.

Gassed (See Figure 3) is a very large oil painting on canvas, $231 \mathrm{~cm} \times 611.1 \mathrm{~cm}$, dominated by a line of ten gassed and blindfolded soldiers being shepherded by a medical orderly along a duckboard path towards the CCS reception tent, off canvas to the right. Further away, a line of eight more gas victims, guided by two orderlies, approach obliquely from the right. The duckboards are surrounded by blindfolded soldiers lying down, probably already assessed and treated, and now awaiting an ambulance train to transfer them to a base hospital..$^{51}$

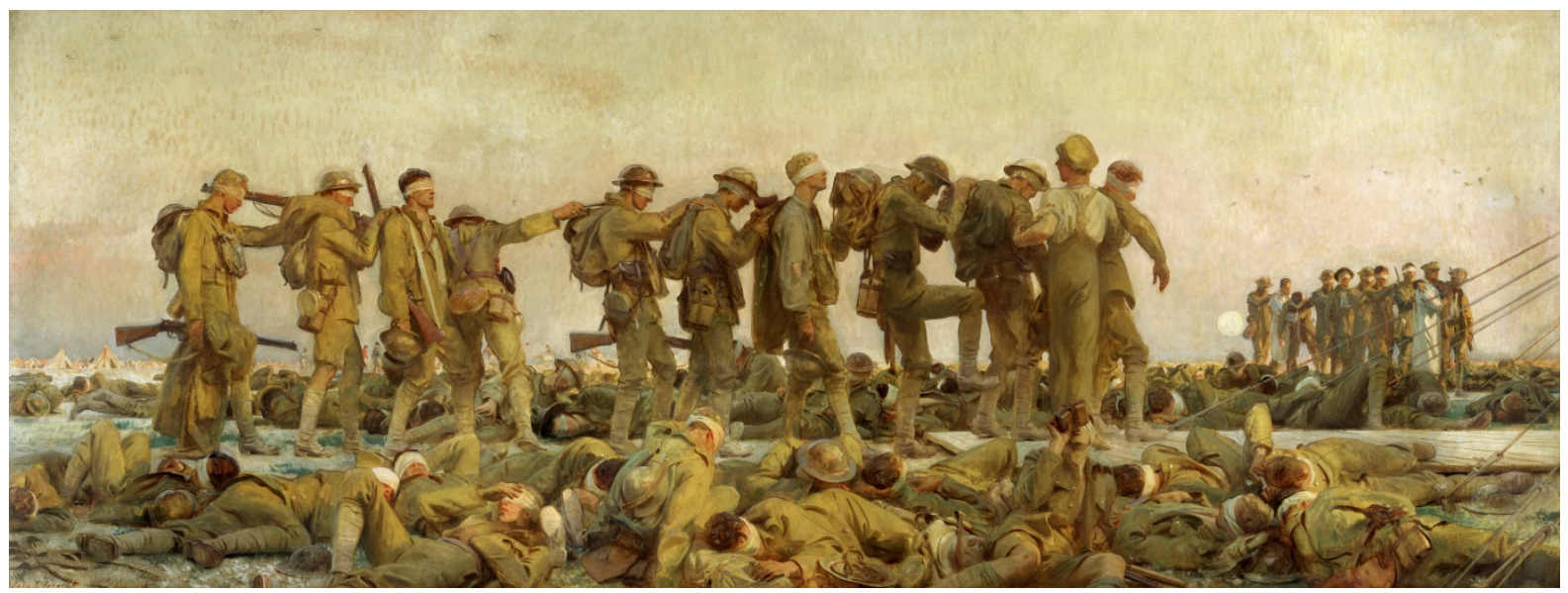

Figure 3. John Singer Sargent, Gassed. Courtesy Imperial War Museum 001460.

In the background to the left is the tented living accommodation of the CCS staff and before that, in the middle ground, a football match is being played between teams dressed in blue and red whilst distant aircraft dog fight above a rising full moon. As is the case with Bone's Artillery Men at Football, the football match in Gassed is difficult 
to see at first glance and is often missed by the casual observer as it is only visible through gaps in the central line of wounded soldiers.

The place of a football match in a painting giving an 'overall impression of loss and suffering' has been debated. ${ }^{52}$ However, given Sargent's recognition of himself as a representational painter, 'I do not judge, I only chronicle', and Vernon Lee’s opinion that 'his conscious endeavour, his self-formulated programme, was to paint whatever he saw with absolute and researchful fidelity, never avoiding ugliness nor seeking after beauty', it can be concluded that quite probably there was a football match occurring at the time of his visit to the 46 CCS. ${ }^{53}$ Given the number of casualties at the CCS, the occurrence of a football match seems inhumane. However CCSs worked around the clock in six hour shifts dealing with 'an endless flow of carnage ... smocks drenched in blood, with the nauseating scent of sepsis and cordite and human excrement'. In response to the strain, staff sought 'to find their own peace in the midst of the madness. ${ }^{54}$ Howard Somervell, a surgeon attached to 34 CCS, would escape with his fellow officers to 'picnic in the copses of oaks and maples behind the line ... where larks and robins sang, and the dread and anxiety and physical pain of exhaustion could be for a moment forgotten. Thus the war became a dream, an inversion of reality' ${ }^{55}$ No doubt many of the CCSs staff, like their colleagues in other units played football to escape their reality in their off-duty periods. The staff were no different from other British army units and had to be kept fit, develop and retain team spirit, and get relief from the pressures of the job.

Most commanding officers would have encouraged sport wherever and whenever it was possible. Sister Edith Appleton of 3 CCS recorded in August 1915; 'Very busy morning - two men are dying and many, many dressings to do.... Our sisterin-charge does not approve of us taking part in the sisters' egg-and-spoon race at the 
inter-clearing station sports on Saturday ... she (old fool) thought it "unladylike", ${ }^{56}$ Like Somervell, Appleton liked to walk and picnic to escape; 'I heard they have been shelling in St-Jans-Chappel today - so I am glad we did not take our off-duty walk there. There is a baseball match at No. 8 today, which I hope to dodge. I would rather learn lace-making than watch rounders' ${ }^{57}$ Even the peripatetic ambulance train crews participated when possible, in December 1914 an anonymous nurse wrote 'we were drydocked today at Sotteville, outside Rouen.... It is lovely to get out of the train. This afternoon No. - played a football match against the Khaki train and got well beaten. They’ve only been in country about eight days, so they are in better training than us, but it will do them a lot of good, we looked on' ${ }^{58}$ Later in December whilst awaiting repairs at Sotteville 'they played another football match this afternoon, and did much better than last time, but still got beaten'. ${ }^{59}$

The fact that the players in Gassed are in football kit suggests that this is a formal competitive match rather than a scratch kick-about as portrayed by Begg and Bone; the shortage of sports kit meant that it was normally issued for matches and then returned. ${ }^{60}$ The lack of onlookers implies a low level game, perhaps between sections, rather than an inter-unit match as spectators were an institutionalized element of that level of game from $1916 .{ }^{61}$ Also with the Third Battle of Albert in progress it is doubtful that transport could have been arranged to bring another unit to a football match. The full kit and vigorous activity of the footballers contrasts sharply to the halting progress of the bandaged infantrymen. It would have been easy for Sargent to omit a football match he observed; perhaps his short time with British forces had revealed the omnipresence of football and, by including it, he adds to the pathos that this type of scene is normal and life goes on around it. ${ }^{62}$ 


\section{Concluding Thoughts}

The three works of art help to trace the process by which sport in the British Army developed 'from a mainly spontaneous and improvised pastime in the early stages of the war into a compulsory activity for troops out of the line by the last months of the conflict'. ${ }^{63}$ In the early days of WWI, it was believed that it would be 'over by Christmas' and signs that this war was a permanent or semi-permanent state of affairs were not encouraged. Begg's illustration captures this impermanence and confidence; there is time and energy to play football but no need to build fixed camps with ancillary facilities.

Sport became an official part of army training at about the same time as Bone's Artillery Men at Football was drawn. The war had been dragging on for two years and the public was becoming concerned at the mounting losses in the wake of Loos and The Somme. It is hard to evaluate the effect of Bone's portfolio at that time of renegotiation of national identity but 'the realism, uniformity and appeal to truthfulness' of his output would have appealed more to opinion leaders than the mass of the population as Begg's style had done. ${ }^{64}$ Bone’s soldiers are quintessentially English, stoical and decent, getting on with the job and playing football when the opportunity arises. The camp is ordered and semi-permanent, the war is not of Britain's choosing, but it will be seen through however long it takes to overcome German aggression and destruction and then the troops will return home.

Gassed has become symbolic of the Great War as national trauma in a manner similar to Paul Nash's landscapes. The poet, Wilfred Owen wrote in the preface to a volume of poetry that was never published 'Above all I am not concerned with poetry. My subject is War, and the pity of war. The poetry is in the pity,' no doubt Sargent may have had similar feelings about his work Gassed. ${ }^{65}$ The duckboards and the patience and 
resignation of the injured infantrymen perhaps reflect the general feeling that it had been a long and costly war with no end to the suffering in sight.

All three images reinforce the October 1917 observation of James Jack, by now a major and commander of the 2/West Yorkshire Regiment, that 'no British troops ever travel without footballs or the energy to kick them' ${ }^{66}$ Fuller points to the soldiers' experiences behind the lines as underpinning the British army's excellent morale; the rotation system of regularly bringing units out of the front line allowed the men to carry over aspects of their civilian life into their new world, helping them to adjust and humanise the experiences. The recreations of mass society proved to be appropriate to mass warfare; 'it was precisely because the war was so terrible, so hideous a reality after the civilians' dreams of glory, that men to survive had periodically to escape. ${ }^{97}$

The rapid proliferation of football in the British army had been, for all intents and purposes, a bottom up process. Junior officers had recognised its importance and encouraged, or at least facilitated, their men's participation. Its effects were formally recognised by the same document that changed infantry tactics, The General Staff's S.S.143 Instructions for the Training of Platoons for Offensive Action 1917. The 1918 edition stated:

Too much attention cannot be paid to the part played by games in fostering the fighting spirit. They afford the platoon commander an unrivalled opportunity not only of teaching his men to play for their side and work together in the spirit of self sacrifice, but of gaining insight into their characters. He should not only personally and actively arrange for games and competitions for his men, but take part in them himself. If he induces his platoon to be determined to produce the best football team in the battalion, he will have done a great deal to make it the best platoon in every way. ${ }^{68}$

All three images portray that the British soldier's sporting spirit was intact and, even after the war, some saw this as vital to the victory. The artworks are in different styles but may be interpreted as accurately representing how football was being played 
at the front and provide important illustrations of a soldier's life away from the trenches. At the Royal Academy banquet of 1919, Field Marshall Douglas Haig, who spoke after The Prince of Wales, stated 'the war had been a very long one, and of an intensity unexampled in all history. It was mainly due to the feeling of loyalty which existed in all ranks of the army, and to each one "playing the game" in the most unselfish spirit, as true English sportsmen, that we had won'. ${ }^{69}$ But, by 1917 army football had, by and large, assumed its civilian working-class mantle with well organised tournaments and where winning was paramount, perhaps a fortunate mind-set development in a mass technological war. Sport had played an important part in the lives of soldiers between 1914 and 1918, sustaining morale, developing fitness and team loyalty, providing amusement, reminding them of their civilian lives and home, and generally making life bearable whilst distracting them from the horrors of the front line.

Gassed was shown at the Royal Academy Summer Exhibition of 1919 and The

Times in its 'First Notice’ reported:

The "picture of the year" is of course Mr. Sargent's "Gassed", lent by the Imperial War Museum. It should be seen first from a distance...It is a picture which no critic could pretend to judge finally at a first seeing. The intention is clear is at once. A train of soldiers, gassed, blinded, and bandaged, is led across the canvas, no doubt from a clearing station, to some place of rest. The ground is crowded with soldiers lying down and also gassed; and there is another train moving on the right of the canvas. Far behind are soldiers playing football; and this background is a kind of counterpoint to the procession of pain in front. ${ }^{70}$

\section{Notes}

\footnotetext{
${ }^{1}$ Campbell, 'The Army isn't all work'; Fuller, Troop Morale and Popular Culture; Mason and Reidi, Sport and the Military; Roberts, 'The Best Football Team'; Veitch, 'Play Up! Play Up!'

${ }^{2}$ Begg, Samuel, In the Wings of the Theatre of War: Behind the centre of the fighting line in Belgium, (The Illustrated London News, December 5, 1914, 776-777).

${ }^{3}$ Bone, Muirhead, Artillery Men at Football is currently in the Imperial War Museum archives (Art.IWM ART 2182) and due to conservation policies is not available as a high definition image. Records seem to indicate that this image has not been displayed to the public in over seventy years. It does not appear to have been published during the war and may, for some reason, be one of the scores of
} 
drawings by Bone that were held back by a censor. According to his son Sylvester Bone, Sir Muirhead Bone, his first batch of completed drawings for Wellington House comprised of over 80 drawings but they received only 50 after military censorship.

${ }^{4}$ Sargent, John Singer. Gassed is permanently displayed in the IWM's Sargent Gallery.

${ }^{5}$ Lomas, First Ypres 1914; Hart, History of the First World War; Moorhouse, Forged by Fire; Stevenson, 1914-1918.

${ }^{6}$ There were instances of smuggled cameras at the front and the Imperial War Museum has a sizeable collection of unauthorized photographs. Several newspapers published such photographs of 'The Christmas Truce' of 1914.

${ }^{7}$ Hichberger, Images of the Army, 93.

8 Johnson, Front Line Artists, 165-166.

9 Ibid., 167.

${ }^{10}$ Cork, A Bitter Truth, 125.

${ }^{11}$ Houfe, Dictionary of 19th Century British Book Illustrators; Thorpe, English Illustration.

${ }^{12}$ Several British cavalry units fought, with distinction, dismounted as infantry at First Ypres.

${ }^{13}$ Mason and Riedi, Sport and the Military.

${ }^{14}$ Diaper, 'Kicking Football to the Front'.

${ }^{15}$ Elpherstone, Alfred. 'Unpublished diary 1915-1916', East Surrey Regiment Archives, Surrey History Centre, Guildford, Cited by Diaper, 'Kicking Football to the Front', 219.

${ }_{16}$ Mason and Riedi, "'Leather" and the fighting spirit'.

${ }^{17}$ Army Athletic Association, W032/5492, The National Archives cited by Mason and Reidi, Sport and the Military, 48.

${ }^{18}$ Terraine, General Jack's Diary, 57, 91.

19 The Sporting Life, November 23, 1914; The Daily Mail, November 30, 1914.

20 The Sporting Life, November 30, 1914.

${ }^{21}$ XI Hussar Journal, October 1915, VI: 42-44, E.85/86. Imperial War Museum.

${ }^{22}$ Terraine, General Jack's Diary, 91. Athletic News, November 1, 1915. Cited by Mason and Riedi, Sport and the Military, 87.

${ }^{23}$ Mason and Riedi, '"Leather" and the fighting spirit'.

${ }^{24}$ Ibid.

${ }^{25}$ Nicholls, Cheerful Sacrifice, 12. Maxse, Ivor. 'Agenda, Divisional Commander's Conference' April 26, 1916. Maxse Papers. Imperial War Museum File 17/2, 2.

${ }^{26}$ Hart, The Somme.

27 Baynes, Morale.

${ }^{28}$ Roberts, 'The Best Football Team'.

${ }^{29}$ Mason and Riedi, '"Leather" and the fighting spirit'.

${ }^{30}$ Roberts, 'The Best Football Team', 39.

${ }^{31}$ Malvern, Modern Art, Britain and the Great War.

32 Bone, Sir Muirhead Bone, 86.

33 Brandon, Art \& War.

${ }^{34}$ Bond, 'The Somme in British History', 196. Bond points out that some reporters such as W. Beach Thomas became notorious with the troops because of the deceitful picture they conveyed. Caton Woodville's romantic and patriotic illustration of Captain Nevill of the Eighth East Surrey's leading the attack on July 1, 1916, The Surreys Play the Game (ILN, July 29, 1916, 134$135)$, typifies the popular notion of war as the greater game.

${ }^{35}$ Bone, Sir Muirhead Bone, 86.

${ }^{36}$ Art from the First World War; Gough, A Terrible Beauty.

${ }^{37}$ The Crawford Centre for the Arts, Muirhead Bone, np.

${ }^{38}$ Malvern, Modern Art, Britain and the Great War.

${ }^{39}$ Bone: Sir Muirhead Bone.

${ }^{40}$ Muirhead Bone: 1876-1953.

${ }^{41}$ Art from the First World War, np.

${ }^{42}$ Campbell, 'The Army isn't all work'.

${ }^{43}$ Gough, A Terrible Beauty, 51.

${ }^{44}$ Letter from Bone to Ffoulkes, IWM, March 31, 1929. Imperial War Museum 43A/2: Muirhead Bone, February 1928-December 1935. 
45 Johnson, Front Line Artists.

${ }^{46}$ Gough, A Terrible Beauty, 26. The proposed Hall was never built and the collection of paintings was given to the IWM.

47 Yockney to Sargent, April 26, 1918. In a letter to Bone, another committee member of the BWMC, Yockney wrote that Sargent was the 'keystone of the arch' of the project, October 10, 1918, IWM First World War Artists Archive 284A-7 John Sargent 1918-1924. In response to Yockney, Bone thought the BWMC should 'humour Sargent in every possible way', IWM First World War Artists Archive, 39/2 part 1. IWM, London.

48 Tonks, Henry. Letter to Alfred Yockney, March 19, 1920. Imperial War Museum ART/WA/329.

${ }^{49}$ Sargent, John. Letter to Charteris, September 11, 1918, cited in Charteris, John Sargent, 214

${ }^{50}$ Tonks, Henry. Letter to Alfred Yockney, March 19, 1920. Imperial War Museum ART/WA/329.

${ }^{51}$ CCS's were often by railway tracks to facilitate the transfer of wounded troops. The line, immediately south of the position of 46 CCS, is now a cycle track. Research visit September 10, 2013.

${ }^{52}$ Art from the First World War, np. Adams and Hughson, 'The first ever anti-football painting?'

${ }^{53}$ Charteris, John Sargent, 107. Lee, 'In Memoriam', 251.

${ }^{54}$ Davis, Into the Silence, 18, 19.

${ }^{55}$ Ibid., 21.

${ }^{56}$ Cowen, A Nurse at the Front, 46-47.

57 Ibid., 49.

${ }^{58}$ Anonymous, Diary of a Nursing Sister, Saturday, December 19, 1019. Khaki trains were converted British rolling stock rather than French.

59 Ibid., Tuesday, December 29, 1914.

${ }^{60}$ Campbell, 'The Army isn't all work'.

${ }^{61}$ Roberts, 'The Best Football Team'.

${ }^{62}$ Adams and Hughson, 'The first ever anti-football painting?'

63 Mason and Riedi, '"Leather" and the fighting spirit', 485.

${ }^{64}$ Malvern, Modern Art, Britain and the Great War, 28.

${ }^{65}$ O'Flinn, 'Wilfred Owen', This preface was found amongst Owen's papers after he was killed by a sniper on November 4, 1918.

${ }^{66}$ Terraine, General Jack's Diary, 227

${ }^{67}$ Fuller, Troop Morale and Popular Culture', 176.

${ }^{68}$ SS143 Instructions for the Training of Platoons for Offensive Action (40/WO/5868). Maxse papers, Imperial War Museum.

${ }^{69}$ Royal Academy Banquet, The Times, May 6, 1919.

70 The Royal Academy: A First Notice, The Times, May 3, 1919, 15.

\section{References}

Adams, Iain and John Hughson. "'The first ever anti-football painting”? A consideration of the soccer match in John Singer Sargent's Gassed'. Soccer \& Society 14, no. 4 (2013): 502-514.

Anonymous. Diary of a Nursing Sister on the Western Front, 1914-1915. Edinburgh and London: William Blackwood \& Sons, 1915.

Art from the First World War. London: Imperial War Museum, nd.

Baynes, John. Morale: A Study of Men and Courage. Barnsley: Pen \& Sword, 1987.

Bond, Brian. 'The Somme in British History' In War in the Age of Technology: Myriad Faces of Modern Armed Conflict, ed. Geoffrey Jensen and Andrew West, 194210. New York: New York University Press, 2001.

Bone, Sylvester. Sir Muirhead Bone: Artist and Patron. London: Bayham Publishing, 2009.

Brandon, Laura. Art and War. London: I.B. Tauris, 2007.

Campbell, James Dunbar. 'The Army Isn't all work: Physical culture in the evolution of the British Army, 1860-1920'. PhD diss., University of Maine, 2003. 
Charteris, Evan, ed. John Sargent. New York: Charles Scribner’s Sons, 1927.

Cork, Richard. A Bitter Truth: Avant-Garde Art and the Great War. London: Yale University Press, 1994.

Cowen, Ruth, ed. A Nurse at the Front: The First World War Diaries of Sister Edith Appleton. London: Simon and Schuster, 2012.

Davis, Wade. Into the Silence: The Great War, Mallory and the Conquest of Everest. London: The Bodley Head, 2011.

Diaper, Ashley. 'Kicking Football to the Front: An Investigation into the Role of English Football during the Great War 1914-1918'. MA thesis, University of Central Lancashire, 1997.

Forster, Edward M. Abinger Harvest and England's Pleasant Land. London: Andre Deutsch, 1996.

Fuller, J.G. Troop Morale and Popular Culture in the British and Dominion Armies 1914-1918. Oxford: Clarendon Press, 1990.

Gough, Paul. A Terrible Beauty: British Artists in the First World War. Bristol: Sansom \& Co., 2010.

Hart, B.H. Liddell. History of the First World War. London: Cassell and Company, 1970.

Hart, Peter. The Somme. London: Weidenfeld \& Nicolson, 2005.

Hichberger, Joan Winifred Martin. Images of the Army: The Military in British Art. Manchester: Manchester University Press, 1991.

Houfe, Simon. Dictionary of 19th Century British Book Illustrators and Caricaturists. London: Antique Collectors' Club, 1996.

Johnson, Peter. Front Line Artists. London: Cassell, 1978.

Lee, Vernon. 'J.S.S.: In Memoriam’. In John Sargent, ed. Evan Charteris, 235-255. New York: Charles Scribner's Sons, 1927.

Lomas, David. First Ypres 1914: The Graveyard of the Old Contemptibles. Oxford: Osprey, 2012.

Malvern, Sue. Modern Art, Britain and the Great War. London: Yale University Press.

Mason, Tony and Eliza Riedi. Sport and the Military: The British Armed Forces 18801960. Cambridge: Cambridge University Press, 2010.

Mason, Tony and Eliza Riedi. "'Leather" and the Fighting Spirit: Sport and the British Army in World War I'. Canadian Journal of History 41, no. 3 (2006): 485-516.

Moorhouse, Brendon. Forged by Fire: The battle tactics and soldiers of a World War One Battalion, The $7^{\text {th }}$ Somerset Light Infantry, Staplehurst: Spellmount, 2003.

Muirhead Bone: 1876-1953. Edinburgh: The Fine Art Society, 1990.

Nicholls, Jonathon. Cheerful Sacrifice: The Battle of Arras. Barnsley: Pen and Sword, 2006.

O’ Flinn, Paul. 'Wilfred Owen: Poetry, War \& Pity'. Socialist Review, 7 (1978): 29-30.

Roberts, James. "'The Best Football Team, The Best Platoon”: The Role of Football in the Proletarianization of the British Expeditionary Force, 1914-1918'. Sport in History 26, no. 1 (2006): 26-46.

Stevenson, David. 1914-1918: The History of the First World War. London: Penguin, 2004.

Terraine, John, ed., General Jack's Diary: War on the Western Front 1914-1918. London: Cassell, 2000.

The Crawford Centre for the Arts. Muirhead Bone: Portrait of the Artist. St Andrews: The Crawford Centre for the Arts, 1986. 
Thorpe, James. English Illustration: the 'Nineties. New York: Hacker Art Books, Inc., 1975.

Veitch, Colin. 'Play Up! Play Up! And win the war! Football, the Nation and the First World War'. Journal of Contemporary History 20 (1985): 363-378. 